\title{
PELATIHAN MELIPAT PAPERCRAFT BAGI GURU DAN ANAK-ANAK TK PERTIWI II KANTOR GUBERNUR KOTA PADANG SUMATERA BARAT
}

\author{
Dwi Mutia Sari ${ }^{1 *}$, Eko Purnomo ${ }^{2 *}$, Rifqi Aulia Zaim ${ }^{3 *}$ \\ Program Studi Desain Komunikasi Visual, Jurusan Seni Rupa \\ Fakultas Bahasa dan Seni \\ Universitas Negeri Padang \\ Jl. Prof. Dr. Hamta, Air Tawar Padang, Kel. Air Tawar Barat, Kec. Padang Utara, Kota Padang, Kode Pos 25171 \\ Sumatera Barat. Indonesia \\ Email: belutlaut@gmail.com
}

\begin{abstract}
Abstrak
Perkembangan motorik halus pada anak-anak usia prasekolah sangat penting utuk perkembangan otak anak lebih lanjut di usia sekolah, untuk itu diperlukan latihan-latihan yang dapat membantu perkembangan motorik tersebut diantaranya latihan melipat papercraft bagi anak usia prasekolah ini. Hal tersebutlah yang melatarbelakangi pengabdian ini agar anak-anak usia prasekolah ini dapat melipat papercraft menarik yang sudah disediakan nantinya. Kegiatan ini disampaikan dalam bentuk pemahaman dengan metode ceramah, peragaan dan demonstrasi sekitar 30\% dari keseluruhan kegiatan pelatihan. Sedangkan kegiatan pelatihan diberikan dengan metode resitasi, bimbingan individual, peragaan dan demonstrasi dengan jumlah waktu sekitar $70 \%$ dari keseluruhan kegiatan pelatihan. Hasil pelatihan melipat papercraft memiliki tujuan mengedukasi guru dan anak-anak TK dalam meningkatkan perkembangan motorik halus anak-anak yang berguna sebagai persiapan menulis serta megedukasi anak-anak usia prasekolah untuk mampu menciptakan mainan sendiri.
\end{abstract}

Kata Kunci: melipat, motorik halus, papercraft.

\begin{abstract}
In preschool, fine motor development is very important for further brain development of children at school age,for that we need exercises to help development it as folding papercraft exercises. The background of this dedication so that preschoolers can fold the papercraft that has been provided later. This activity was delivered in the form of understanding using lecture, ostentation and demonstration methods around $30 \%$ of the total training activities. While the training activities are given by recitation method, individual guidance, ostentation and demonstration with the amount of time around $70 \%$ of the total activities. The results of this papercraft folding training have the aim of educating teachers and children in enhancing the fine motor development which is useful as a preparation for writing and educating preschoolers to be able to create their own toys.
\end{abstract}

Keywords: fold up, fine motor, papercraft.

\section{PENDAHULUAN}

Taman Kanak-kanak Pertiwi II Gubernur Kota Padang berada di Jalan Merpati Induk Kelurahan Air Tawar Barat Kecamatan Padang Utara Kota Padang Sumatera Barat. Jarak antara perguruan tinggi Universitas Negeri Padang dengan TK Pertiwi II Gubernur Kota Padang lebih kurang 1 km. TK Pertiwi II Kantor Gubernur Kota Padang dikepalai oleh Ibu Nesti, S.Pd.

Menurut keterangan dari Beliau, kegiatan Pengabdian Kepada Masyarakat (PKM) seperti pelatihan untuk guru dan anak-anak ini belum pernah dilakukan. Oleh sebab itu, sebagai Kepala Sekolah, beliau sangat tertarik dan antusias sekali dalam mendukung kegiatan pengabdian ini karena untuk meningkatkan perkembangan motorik halus pada anak, guru sebagai pengajar perlu menyediakan media pembelajaran guna mengembangkan kretivitas anak. Selain itu, anak-anak juga menyukai kegiatan mencetak, menggunting, membentuk dan menempel benda-benda bergambar yang jarang dan belum pemah mereka lakukan sebelumnya. Semua kegiatan tersebut ditemukan dalam kegiatan melipat papercraft karena kegiatan menggunting dan menempel merupakan unsur utama dari melipat papercraft.

Heroman (2002) mengatakan perkembangan motorik halus mengatur penggunaan otot kecil pada tangan untuk menulis dan dengan terampil. Karena ketika otot kecil berkembang maka anak mampu melakukan keterampilan membantu diri sendiri dan memanipulasi benda-benda kecil seperti gunting dan menggunakan 
alat tulis. Kegiatan melipat papercraft tersebut merupakan salah satu kegiatan yang dapat membantu realisasi perkembangan motorik halus dari anak-anak TK ini.

Selama ini, guru dan anak-anak TK Pertiwi II Kota Padang Kantor Gubernur Sumatera Barat mengembangkan seni dan motorik halus hanya menggunakan media mewamai gambar saja sehingga kemampuan seni dan motorik halus anak-anak tidak berkembang secara optimal. Oleh karena itu, dengan bantuan kegiatan melipat papercraft ini diharapkan dapat mengedukasi guru untuk mengembangkan seni, dan motorik halus anak-anak TK Pertiwi II Kantor Gubernur Kota Padang Sumatera Barat dan menuangkan imajinasinya.

Selain itu, melipat papercraft juga dapat mengembangkan kreativitas anak-anak TK Pertiwi II Kantor Gubernur Kota Padang Sumatera Barat karena anak-anak juga dirangsang berpikir kritis dan mengeluarkan ide-ide kreatifnya sehingga dapat menghasilkan karya sendiri.

Berangkat dari fakta di atas, selain berdampak terhadap pengembangan seni dan motorik halus anak-anak, dalam kegiatan melipat papercraft ini guru dan anakanak juga mampu menuangkan ide-ide kreatif dalam melipat paper craft.

Oleh karena itu, pelatihan tersebut diadakan di TK Pertiwi II Kantor Gubernur Kota Padang Sumatera Barat. Karena untuk mengatasi masalah yang ada tersebut pengabdian kepada masyarakat ini mencoba mencarikan altematif penyelesaian yaitu dengan kegiatan melipat papercraft. Karena diharapkan dengan adanya kegiatan ini dapat mengedukasi guru dalam membuat kegiatan yang merangsang perkembangan motorik anak secara optimal. Untuk itu pengabdi tertarik melakukan pengabdian tentang "Pelatihan Melipat Papercraft Bagi Guru dan AnakAnak Tk Pertiwi II Kantor Gubernur Kota Padang Sumatera Barat"

\section{KAJIAN TEORI}

\section{Melipat}

Sumanto (2003) menjelaskan bahwa melipat atau origami adalah suatu teknik berkarya seni/ kerajinan tangan yang umumnya dibuat dari bahan kertas origami dengan tujuan untuk menghasilkan aneka bentuk main, hiasan, benda fungsional, alat peraga dan kreasi lainnya. Oleh sebab itu, kegiatan melipat papercraft menjadi salah satu pilihan kegiatan yang dapat mendukung perkembangan motoeik halus anak.

\section{Motorik Halus}

Depdiknas (2008 : 10) menjelaskan bahwa motorik halus adalah gerakan yang melibatkan bagian-bagian tubuh tertentu yang dilakukan oleh otot-otot kecil (halus) serta memerlukan koordinasi yang cermat, seperti menggunting mengikuti garis, menulis, meremas, menggenggam, menggambar, menyusun balok, memasukkan kelereng ke dalam lubang, membuka dan menutup objek dengan mudah, menuangkan air ke dalam gelas tanpa berceceran, menggunakan kuas, krayon dan spidol, serta melipat kertas.

Menurut Peraturan Menteri Pendidikan Nasional Nomor 58 Tahun 2009, tingkat pencapaian perkembangan motorik halus anak usia 5-6 tahun meliputi: (1) menggambar sesuai gagasannya (2) meniru bentuk, (3) melakukan eksplorasi dengan berbagai media dan kegiatan, (4) menggunakan alat tulis dengan benar, (5) menggunting sesuai dengan pola, (6) menempel gambar dengan tepat, (7) mengekspresikan diri melalui kegiatan menggambar secara detail.

\section{Papercraft}

Semua orang mengenal papercraft sebagai seni kerajinan kertas sebagai medianya untuk membuat objek-objek tiga dimensi dengan cara seperti menggambar model, menggunting, mengelem dan mewarnainya (Sulianta, 2010). Papercraft ini biasanya terbuat dari kertas tebal seperti inject matte, karton yang berukuran diatas $100 \mathrm{gsm}$.

\section{METODE PENELITIAN}

Pemecahan masalah dilakukan dengan jalan keluar PKM berupa pemahaman mengenai pentingnya edukasi pelatihan melipat papercraft bagi guru dan anak-anak Taman Kanak-kanak Pertiwi II Kota Padang Sumatera Barat guna meningkatkan kemampuan motorik halus anak-anak usia prasekolah yang akan menunjang kegiatan pembelajaran mereka nantinya. Adapun kegiatan pemahaman tersebut diberikan dengan metode ceramah tanya jawab, peragaan dan demonstrasi. Sedangkan kegiatan pelatihan melipat papercraft diberikan dengan metode bimbingan individual, peragaan dan demostrasi.

Dalam proses pelaksanaannya sendiri, kegiatan yang ditawarkan untuk jalan keluamya adalah:

\section{Survey}

Merupakan peninjauan lokasi kegiataan pengabdian akan berlangsung serta informasi terkait jumlah peserta yang terlibat nantinya di dalam kegiatan pengabdian 


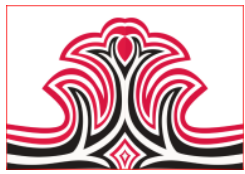

ini.

\section{Pelaksanaan}

Mencetak desain model papercraft

Desain model yang sudah disediakan dicetak di kertas inkjet matte double side 220gsm ukuran A4 menggunakan printer warna. Guru dan anak-anak TK diberikan desain model dasar yang sudah disediakan.

\section{Penerapannya}

Desain yang sudah dicetak di kertas A4 inkjet matte double side $220 \mathrm{gsm}$ tersebut digunting berdasarkan pola yang sudah ada. Hasil cetakan desain papercraft tersebut mulai dilipat dan dibentuk sesuai pola dengan bimbingan individual langsung dengan guru dan anak serta diperagakan bagaimana cara menggunting, melipat dan mengelem papercraft tersebut. Selanjutnya papercraft yang sudah dilipat dan dilem dibentuk sesuai pola karakternya.

\section{Monitoring dan Evaluasi}

Desain model papercraft pertama yang diterapkan perlu dilakukan evaluasi untuk melihat perkembangan materi yang diberikan pada guru dan anak-anak tersebut. Hasil melipat papercraft yang memuaskan akan diberi reward sebagai penghargaan terhadap upaya yang sudah dihasilkan dari membentuk model papercraft tersebut. Pada akhir kegiatan dilakukan evaluasi akhir untuk melihat seberapa jauh materi yang telah ditangkap oleh guru dan anak-anak TK tersebut.

\section{HASIL DAN PEMBAHASAN}

\section{Hasil}

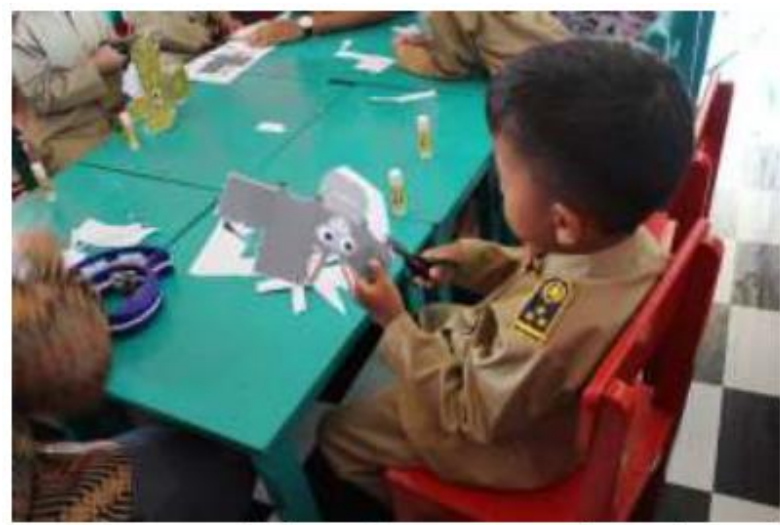

Gambar 1. Proses Pengerjaan Papercraft

(Sumber: Dwi Mutia Sari, 2019)
Gorga : Jurnal Seni Rupa

Volume 08 Nomor 02 Juli-Desember 2019 p-ISSN: 2301-5942 | e-ISSN: 2580-2380

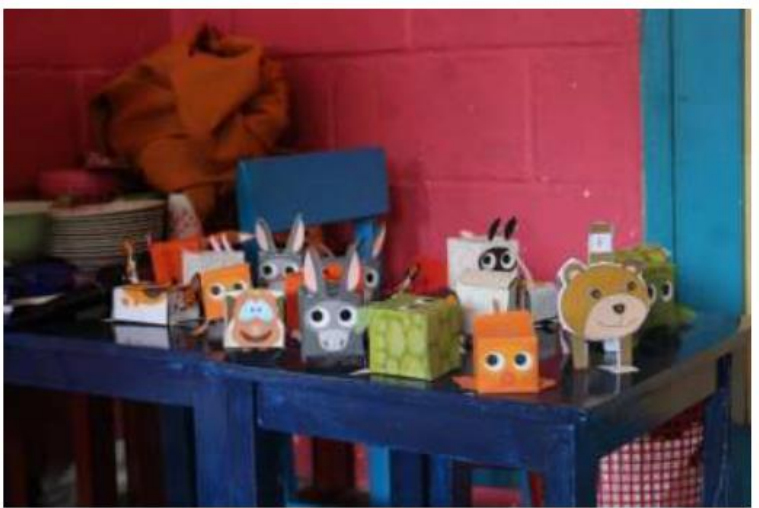

Gambar 2. Hasil Karya Papercraft Siswa (Sumber: Dwi Mutia Sari, 2019)

\section{Pembahasan}

Adapun luaran yang dihasilkan dari kegiatan pelatihan melipat papercraft ini terhadap mitra adalah: Guru dan anak-anak TK Pertiwi II Kantor Gubernur Kota Padang Sumatera Barat belum pernah mendapatkan pengalaman berupa Program Kemitraan Masyarakat (PKM) seperti ini, oleh sebeb itu, pelatihan melipat papercraft ini menjadi pengalaman pertama bai sekolah khususnya guru dan siswa TK Pertiwi II Kantor Gubernur Kota Padang Sumatera Barat sehingga guru mendapatkan edukasi sebuah pengalaman baru dalam mengembangkan kreativitas anak berupa melipat papercraft sebagai salah satu bentuk alternative untuk meningkatkan perkembangan motoric anak-anak usia prasekolah.

Guru dan anak-anak TK Pertiwi II Kantor Gubernur Kota Padang Sumatera Barat ini sudah mampu menggunakan gunting secara benar. Guru dan anakanak TK Pertiwi II Kantor Gubernur Kota Padang Sumatera Barat ini sudah mampu menggunting secara benar sesuai garis. Guru dan anak-anak TK Pertiwi II Kantor Gubernur Kota Padang Sumatera Barat ini sudah mampu melipat kertas sesuai garis gambar model papercraft dengan benar. Guru dan anak-anak TK Pertiwi II Kantor Gubernur Kota Padang Sumatera Barat ini sudah mampu mengaplikasikan lem ke kertas model papercraft dengan benar. Guru dan anak-anak TK Pertiwi II Kantor Gubernur Kota Padang Sumatera Barat ini sudah mampu membentuk model papercraft menjadi bentuk tiga dimensi dengan benar. Sedangkan luaran yang dihasilkan pelatihan melipat papercraft.

\section{KESIMPULA DAN SARAN \\ 1.Kesimpulan}

Dari hasil pengabdian kepada masyarakat di TK Pertiwi II Kota Padang Sumatera Barat bahwa guru dan siswa mendapatkan pengalaman baru dalam mengembangkan kreativitas berupa melipat papercraft sebagai salah satu bentuk alternatif dalam 
meningkatkan perkembangan motorik anak-anak usia prasekolah. Dari hasil pengabdian kepada masyarakat di bidang teori, guru dan siswa dapat memamahami penyampaian materi dengan cukup baik dan dapat diterima oleh guru dan siswa. Dari hasil pengabdian kepada masyarakat di bidang pelatihan/praktek melipat papercraft sudah cukup baik namun pada saat kerja mandiri anak-anak masih kurang memuaskan.

\section{Saran}

Kegiatan pelatihan ini dapat dilaksanakan bagi guruguru TK se Kota Padang nantinya. Kegiatan melipat papercraft ini bisa dijadikan alternatif kegiatan bagi guru dan siswa dalam pembelajaran selanjutnya. Dapat diadakan pengabdian lanjutan dengan pemberian materi yang lebih bertingkat. Pelaksanaan pengabdian dengan jangka waktu yang lebih panjang namun singkat dalam setiap pertemuannya mengingat sulitnya memfokuskan konsentrasi anak-anak TK dalam pemberian materi jika melibatkan siswa nantinya.

\section{DAFTAR RUJUKAN}

Depdiknas. (2008). Pengembangan Motorik Halus Anak di Taman Kanak-Kanak. Jakarta:

Peraturan Menteri Pendidikan Nasional Nomor 58. (2009). Tentang Standar Pendidikan Anak Usia Dini, diakses tanggal 25 September 2019.

Sulianta, Feri \& Variant, Johan. (2010). PaperCraft Dari Desain Kreatif Hingga Bisnis. Jakarta: PT. Elex Media Komputindo.

Sumanto. (2003). Pengembangan Kreativias Seni Rupa Anak TK. Jakarta: Indeks. 